Webology, Volume 17, Number 1, June, 2020

\begin{tabular}{|l|l|l|l|}
\hline Home & Table of Contents & Titles \& Subject Index & Authors Index \\
\hline
\end{tabular}

\title{
How To Make Biodiversity Articles Highly Cited?
}

\author{
Ambar Yoganingrum \\ Research Center for Informatics, Indonesian Institute of Sciences, Cibinong Science Center, \\ Cibinong, Indonesia. ORCID: 0000-0003-3618-759. E-mail: amba002@lipi.go.id
}

Received January 15, 2020; Accepted March 3, 2020

\section{Abstract}

Previous research showed that Indonesia produced the highest number of papers in biodiversity among three mega-diverse Southeast Asia countries, including Indonesia, Malaysia and Philippines. However, among them Indonesia papers received the smallest number of citation. This research aims to identify and compare the characteristics of Indonesian biodiversity papers to Malaysia and Philippines. Firstly, the paper reviewed a set of papers collected from Scopus systematically to find factors for making highly cited articles. Then, the paper applied the factors to find various reasons of low citations. Resulting showed that there are 12 aspects to produce articles highly cited, namely Funding; Number of articles; Subject; Journal; Authorship; Collaborator; Methodology; Pages, tables, illustrations and References; Editorial Factor; Language; Source type; and Getting Award. This paper provides a receipt to Indonesian researchers in creating articles that are potential to be highly cited articles.

\section{Keywords}

Biodiversity; Research impact; Indonesia; Malaysia; Philippines; Highly Cited Articles

\section{Introduction}

Indonesia is one of the seventeen-mega diverse countries, which become host to the most of various species on the Earth. Science and research of Indonesian biodiversity become important since Indonesia is home of 17 percent of the total species of birds fifth rank in the world, 12 percent of the world's mammals second rank, 270 species of amphibians sixth ranks in the world, 16 percent of the world's reptiles, 35 species of primate fourth ranks in the world, 10 percent of 
the world's flowering species with 55 percent is endemic, and the world's centers for agro biodiversity of plant cultivars and domesticated livestock (Secretariat, 2017). Moreover Indonesia also home to around 80 percent of the world medicinal plants (Elfahmi et al., 2014).

Comparing to other mega diverse Southeast Asia countries, Philippines and Malaysia, Indonesia lies on the first ranking in number of publication in biodiversity. However, Indonesia is at the second in the total citations of publications with at least one local author and at the last with a local author as the first author (Yoganingrum, 2018). Highly cited publications give predicate to authors as distinction and claim as the most active research, visible, and important topics in the specialty areas (Clarivate Analytics, 2017). Articles highly cited also indicate high contribution in the development of methods and concepts (Barbosa \& Schneck, 2015; Ciliberto et al., 2009; Peter, 2009; Viglietto, 2009), as well as become fundamental reference of a certain topic.

Recent works had identified several factors to make Highly Cited Articles (HCA) in biodiversity. However, they focused only on six factors namely number of articles (Parker et al., 2013), kind of subject (Barbosa \& Schneck, 2015; Ma et al., 2013; Nardi et al., 2016; Ríos-Saldaña et al., 2018), level and/or specific title of journal (Parker et al., 2013; Pyšek et al., 2006), kind of journal (Parker et al., 2013), number of authors (Barbosa \& Schneck, 2015; Parker et al., 2013), and study design/method (Westgate et al., 2013). Nevertheless, there are still many important factors should be explored to provide comprehensive data to make article highly cited in biodiversity. According to Tahamtan et al. (2016), who conducting literature review conveyed that there were twenty eight factors affecting articles to be cited. It means that there can be other factors excluding six factors that making HCA in biodiversity. Hence, it is required to gather and summarize the characteristics of HCA from different disciplines to accomplish factors that influence HCA in biodiversity.

To fulfill the gap this paper aims to explore factors making articles highly cited and identify the factors making Indonesian biodiversity articles slightly cited. The research questions are what factors do make article highly cited? And what factors do make Indonesian biodiversity articles slightly cited? Outputs of this paper are factors to make HCA in the field of biodiversity and factors to make HCA in Indonesian biodiversity articles. The first output will accomplish existing factors identified for making HCA in biodiversity. The second will be benefit to be hints for Indonesian biodiversity researchers in publishing articles highly cited.

\section{Materials and Methods}

This research consisted of two steps. Firstly, identifying factors that making HCA in biodiversity by adopting a literature review method. The method consisted of three steps: (i) Determining keywords, (ii) Searching references, and (iii) extracting data. The paper explored factors making HCA from various disciplines including biodiversity. The researcher applied a different strategy 
in searching references between other and biodiversity disciplines. Then the factors making HCA were extracted from both groups of references. Afterwards, the paper analysed the characteristics of Indonesian biodiversity articles by comparing the factors influencing HCA to other megadiverse Asian, Malaysia and Philippines.

\section{Identification of factors making HCA}

\section{- Data collection of other disciplines}

This research included a set of publication consisted of 130 papers. A literature search was conducted between August 4 - September 23, 2018 in the Scopus database. A list of keywords was generated based on studying to articles in Scopus, who discussing about making articles highly cited. Result showed that most articles use term of "highly cited" or "top cited". In order to get appropriate articles, the paper used search strategy "highly cited" IN Title or "top cited" IN Title. Then the results were scoped by publishing year (2013-2017), article and review document type, as well as English language.

\section{- Data collection of biodiversity discipline}

This paper involved a set of publication consisted of 10 papers. The search strategy was "highly cited" IN (Article title, Abstract and Keywords) OR "top cited" IN (Article title, Abstract and Keywords) AND Biodiversity IN (Article title, Abstract and Keywords).

\section{- Data analysis}

By reading the abstracts and articles one by one this paper analyzed and extracted qualitative aspects and abandoned the quantitative aspects of data. This provision was applied since this paper identified HCA from other disciplines that will implement to biodiversity articles. Therefore, the quantitative aspects in the context of biodiversity articles should be further determined.

\section{Analysis the characteristics of Indonesian biodiversity articles}

This step adopted collecting data and analysis method applied by Yoganingrum (2018). Author collected total publications with at least one local author from Scopus with following retrieval strategy: Biodiversity in Title-Abs-Key AND (country name) in Title-Abs-Key AND (country name) in Affiliation country. The period publication was from the beginning to 2017. Then author identified some factors based on information provided by Scopus such as subject area, document type, source title, funding sponsor, source type and language. Author also compared the characteristics among three countries. Since there is no data provided by Scopus on following factors: gender, number of pages and cited references, editorial factor, and getting award, the paper did not show and discuss those factors. 


\section{Results}

\section{Factors that making HCA}

This paper identified twelve categories consisting of fifteen factors making HCA. Four categories with six factors were already identified. Therefore, this paper proposes twelve factors with ten factors to accomplish existing factors. Table 1 presents those categories and factors. Note that the majority of previous studies conducted in this area used bibliometric techniques to investigate the characteristics of highly cited articles. Generally, they studied the characteristics of 100 articles with the highest citations. Most HCA from some disciplines were written by authors from the United States. Moreover, most researchers used Scopus and Web of Science (WoS) as the data resources.

Table 1. Categories and factors for making articles highly cited

\begin{tabular}{|c|c|c|c|c|}
\hline No & Categories & Factors & References from other disciplines & $\begin{array}{l}\text { References from } \\
\text { discipline of } \\
\text { biodiversity }\end{array}$ \\
\hline 1. & Funding & & $\begin{array}{l}\text { (Azer, 2016; Azer, 2017; Azer \& Azer, 2016; M. } \\
\text { S. Khan et al., 2017; Munzer et al., 2017; } \\
\text { Noorhidawati et al., 2017) }\end{array}$ & \\
\hline 2. & $\begin{array}{l}\text { Number of } \\
\text { articles }\end{array}$ & & (Azer, 2016; Ding et al., 2016; Tang et al., 2016) & (Parker et al., 2013) \\
\hline 3. & Subject & & $\begin{array}{l}\text { (Ahmad et al., 2017; Bauer et al., 2016; Bohl \& } \\
\text { Ponce, 2017; Buta et al., 2016; Chen et al., 2015; } \\
\text { Chuang \& Ho, 2014; Dong et al., 2016; Fardi et } \\
\text { al, 2017; Farr et al., 2017; Fu \& Ho, 2015; Fu \& } \\
\text { Ho, 2016; Gong et al., 2017; Halverson et al., } \\
\text { 2014; Hong et al., 2017; Huo et al., 2015; Hussain } \\
\text { et al., 2014; Ipekçi et al., 2017; Khan et al., 2017; } \\
\text { Lenzi et al., 2016; Liu et al., 2016; Mazhari, } \\
\text { 2013; Pagni et al., 2014; Pu et al., 2017; Rangel et } \\
\text { al., 2017; Shao \& Zheng, 2016; Sharma \& } \\
\text { Lawrence, 2014; Tang et al., 2016; Thelwall et al., } \\
\text { 2017; Yang et al., 2014) }\end{array}$ & $\begin{array}{l}\text { (Barbosa \& Schneck, } \\
\text { 2015; Ma et al., 2013; } \\
\text { Nardi et al., 2016; } \\
\text { Ríos-Saldaña et al., } \\
\text { 2018) }\end{array}$ \\
\hline \multirow[t]{3}{*}{4.} & \multirow[t]{3}{*}{ Journal } & $\begin{array}{l}\text { Publishe } \\
\text { d period }\end{array}$ & $\begin{array}{l}\text { (Azer, 2015; Azer, 2017; Brown et al., 2017; } \\
\text { Chuang \& Ho, 2015; Elango \& Ho, 2017; Fu \& } \\
\text { Ho, 2016; González-Betancor \& Dorta-González, } \\
\text { 2017; Khan et al., 2017; Kolle et al., 2017; Pu et } \\
\text { al., 2017; Wilcox et al., 2013; Yang et al., 2014) } \\
\text { (Branch \& Linnell, 2016; Brown et al., 2017; H. }\end{array}$ & \\
\hline & & $\begin{array}{l}\text { Level } \\
\text { and/or } \\
\text { specific } \\
\text { title of } \\
\text { journal }\end{array}$ & $\begin{array}{l}\text { Chen \& Ho, 2015; Chuang \& Ho, 2014, 2015; } \\
\text { Fardi et al., 2017; Fu \& Ho, 2015, 2016; Gong et } \\
\text { al., 2017; Ho, 2014; Ho \& Kahn, 2014; Hsu \& } \\
\text { Ho, 2014; Khan et al., 2017; Khan et al., 2015; } \\
\text { Lenzi et al., 2016; Liu et al., 2016; Mazhari, } \\
\text { 2013; Munzer et al., 2017; Pu et al., 2017; Shao \& } \\
\text { Zheng, 2016; Tang et al., 2016; Yang et al., 2014; } \\
\text { Yi et al., 2013; Yoon et al., 2013; Zhang et al., } \\
\text { 2017) }\end{array}$ & $\begin{array}{l}\text { (Parker et al., 2013; } \\
\text { Pyšek et al., 2006) }\end{array}$ \\
\hline & & $\begin{array}{l}\text { Kind of } \\
\text { journal }\end{array}$ & $\begin{array}{l}\text { (Ding et al., 2016; Gutman, Brown, \& Ho, 2017; } \\
\text { Ho, 2013; Kolle et al., 2017) }\end{array}$ & (Parker et al., 2013) \\
\hline
\end{tabular}




\begin{tabular}{|c|c|c|c|c|}
\hline 5. & Authorship & $\begin{array}{l}\text { Number } \\
\text { of } \\
\text { authors }\end{array}$ & $\begin{array}{l}\text { (Antonakis et al., 2014; Azer, 2016; Azer, 2017; } \\
\text { Azer \& Azer, 2016; Branch \& Linnell, 2016; } \\
\text { Chen et al., 2015; Chuang \& Ho, 2015; Elango \& } \\
\text { Ho, 2017; Ho \& Kahn, 2014; Jin \& Hakkarinen, } \\
\text { 2017; Liu et al., 2016; Mazhari, 2013; } \\
\text { Noorhidawati et al., 2017; Yang et al., 2014) } \\
\text { (Azer, 2016; Azer, 2017; Azer \& Azer, 2016; } \\
\text { Khan et al., 2017) }\end{array}$ & $\begin{array}{l}\text { (Barbosa \& Schneck, } \\
\text { 2015; Parker et al., } \\
\text { 2013) }\end{array}$ \\
\hline 6. & Collaborator & $\begin{array}{l}\text { Collabor } \\
\text { ator } \\
\text { countries }\end{array}$ & $\begin{array}{l}\text { (Ahmed et al., 2017; Azer, 2017; Azer \& Azer, } \\
\text { 2016; Elango \& Ho, 2017; Noorhidawati et al., } \\
\text { 2017) }\end{array}$ & \\
\hline 7. & Methodology & $\begin{array}{c}\text { Study } \\
\text { design/ } \\
\text { method } \\
\text { Type of } \\
\text { paper }\end{array}$ & $\begin{array}{l}\text { (Antonakis et al., 2014; Azagra-Caro et al., 2017; } \\
\text { Azer, 2017; Eshraghi et al., 2013; Gong et al., } \\
\text { 2017; Halverson et al., 2014; Hui et al., 2013; } \\
\text { İpekçi et al., 2017; Mitchell et al., 2017) } \\
\text { (Antonakis et al., 2014; Azer, 2015; Fardi et al., } \\
\text { 2017; Farr et al., 2017; Hussain et al., 2014; } \\
\text { Zhang \& Guan, 2017) }\end{array}$ & (Westgate et al., 2013) \\
\hline 8. & $\begin{array}{l}\text { Pages and } \\
\text { references }\end{array}$ & $\begin{array}{l}\text { Number } \\
\text { of pages } \\
\text { and } \\
\text { reference } \\
\text { s } \\
\end{array}$ & $\begin{array}{l}\text { (Antonakis et al., 2014; Branch \& Linnell, 2016; } \\
\text { Mazhari, 2013) }\end{array}$ & \\
\hline 9. & $\begin{array}{l}\text { Editorial } \\
\text { Factor }\end{array}$ & & (Lin et al., 2016) & \\
\hline 10. & Language & English & $\begin{array}{l}\text { (Buta et al., 2016; Dong et al., 2016; Huo et al., } \\
\text { 2015; Martín-Martín et al., 2016; Shao \& Zheng, } \\
\text { 2016) }\end{array}$ & \\
\hline 11. & Source type & & (Martín-Martín et al., 2016) & \\
\hline 12. & Getting Award & & $\begin{array}{l}\text { (Azer, 2016; Chuang \& Ho, 2014; Mroz et al., } \\
\text { 2016) }\end{array}$ & \\
\hline
\end{tabular}

Following are the descriptions of the factors:

\section{Funding}

Publications receiving funding from private or government in their research process became HCA (Khan et al., 2017; Noorhidawati et al., 2017). Likewise, conveyed by Munzer et al. (2017) that a number of top cited articles in emergency medicine education literature included external funding sources. Otherwise, some researchers said that there was no significant correlation between the number of top cited articles and grants received (Azer, 2016; Azer, 2017; Azer \& Azer, 2016).

\section{Number of articles}

In the field of environment and ecology highly cited researchers were also highly productive, publishing on average well over 100 articles each (Parker et al., 2013). The more number of articles published, the greater the chance of having an HCA (Azer, 2016; Ding et al., 2016; Tang et al., 2016). 


\section{Subject}

Researchers argued that particular subjects in a discipline of biodiversity were potential to be HCA (Barbosa \& Schneck, 2015; Ma et al., 2013; Nardi et al., 2016; Ríos-Saldaña et al., 2018). For example, organisms and vegetation were the hottest research topics in wetland research (Ma et al., 2013). Likewise for other disciplines: Bauer et al., (2016) identified that papers that has subject of collection and exploitation of information in clinical practices; use of the Internet in public communication and commerce; and scientometrics are top cited of the field of Library and Information Science in Web of Science (WoS). Other example highly cited papers on Antarctic field in Science Citation Index Expanded had subject of sea ice, southern ocean, climate change, and ozone depletion (Fu \& Ho, 2016). Meanwhile, fracture was the most discussed topic in orthopedic surgery and its subspecialties (Huo et al., 2015). Moreover, top-cited articles in the islet transplantation field focused on antirejection immunotherapy, biocompatible encapsulations, prolong graft survival, islet transplants efficacy assessments, and islet allografts.

\section{Journal}

Previous researches showed that period of publication influenced articles highly cited. Khan et al. (2017) showed that articles in angioplasty published recently can be a top cited in Scopus. Meanwhile, Fu \& Ho (2016) conveyed that Antarctic articles need three years to obtain citations. Reported electrocardiogram-related articles (Yang et al., 2014) and four journals in the fields of Information Science \& Library Science, Operations Research \& Management Science, Ophthalmology, and Physics Condensed Matter (González-Betancor \& Dorta-González, 2017) need two years to be cited. According to Brown et al. (2017) and Wilcox et al. (2013) each examined occupational therapy and pediatric neurosurgical studied that it was need 4-5 years for a publication to gain citations. Moreover, it needs more than a decade to be HCA in horticulture in Science Citation Index Expanded (Kolle et al., 2017). Then, Chuang and Ho (2015) and Elango and Ho (2017) argued that highly cited papers might not have high citations in early years for Taiwanese and Indian respectively. In contrast, two researchers, who studied the topcited articles in the discipline of problem-based learning (PBL) reported that no significant correlations were found between number of citations and number of years since published (Azer, 2017; Azer, 2015). Meanwhile, Tahamtan et al. (2016) proposed that older and younger papers should be considered in analysis to avoid bias.

Researchers argued that one of characteristics of HCA was published in high impact factor journal (Brown et al., 2017; Gong et al., 2017; Khan et al., 2017; Tang et al., 2016). In the contrary, Chuang and Ho (2015), who identifying Taiwanese articles in SCI-Expanded database and Chuang and Ho (2014) who studying top cited of single authored publication argued that HCA can be published in journals with low impact factors. Similarly, to Pu et al. (2017), who determining the top cited articles in the islet transplantation field and Mazhari (2013) in psychiatry reported that it was no correlation between a journal's impact factor and the number of 
citations. Meanwhile, some researchers prefer to say that HCA of a specific discipline are appeared in specific journals (Branch \& Linnell, 2016; Chen \& Ho, 2015; Dong et al., 2016; Fardi et al., 2017; Fu \& Ho, 2015; Fu \& Ho, 2016; Ho, 2014; Ho \& Kahn, 2014; Hsu \& Ho, 2014; Khan et al., 2015; Lenzi et al., 2016; Liu et al., 2016; Mazhari, 2013; Shao \& Zheng, 2016; Yang et al., 2014; Yi et al., 2013; Yoon et al., 2013; Zhang et al., 2017), although most of those specific journals are categorized as high impact factor journals. For example, most HCA of Electrocardiogram was in journal categorized in cardiac and cardiovascular systems.

Some researchers (Ding et al., 2016; Gutman et al., 2017; Kolle et al., 2017) identified that HCA were found particularly not in general journals. This opinion was supported by Parker et al. (2013) from biodiversity field. In contrast, based on the top-cited articles published in the Science Citation Index Expanded from 1991 to 2010 HCA were obtained in both, journal with multidisciplinary and general scopes (Chen et al., 2015; Chuang \& Ho, 2014; Ho, 2013).

\section{Authorship}

Multi-authored articles would be potential to be HCA. In the field of biodiversity, the opinion was conveyed by Barbosa and Schneck (2015) and Parker et al. (2013). Meanwhile, articles written by multi-authors in the field of Electrocardiogram in Science Citation Index Expanded were categorized as HCA (Yang et al., 2014). Moreover, Branch and Linnell (2016) showed that papers with 5-6 authors were likely highly cited. Likewise, the number of authors exceeded six in 50 studies in the TB research were top cited (Chen et al., 2015). Additionally, Antonakis et al. (2014) explored that articles with multi-authors from highly ranking institutions were highly cited. Subsequently, 100 top cited articles in acute kidney injury were published by teams involving more than 3 authors (Liu et al., 2016). However, some researchers argued that no correlation was found between the number of citations obtained and number of authors (Azer, 2016; Azer \& Azer, 2016). Furthermore, Jin and Hakkarinen (2017) reported that more than half of top cited articles in bioethics were composed by single authors.

Khan et al., 2017) and Azer and Azer (2016) showed that male authors receive more citation than those of female authors. Furthermore, Zhang et al. (2018) found that projects with male Principle Investigators (PI) tended to produce more publications, patents, and total SNIP. On the contrary, no significant correlations were found between the top cited articles and females in authorship (Azer, 2017)(Azer, 2016). Furthermore, the long time being a writer, gender, and well-known authors/organizations/countries had to be considered in analysis (Tahamtan et al., 2016).

\section{Collaborator}

International collaboration papers were prospective to be highly cited (Chuang \& Ho, 2015; Elango \& Ho, 2017; Noorhidawati et al., 2017). Strong correlations were found between the topcited articles and number of countries involved (Azer, 2017; Azer \& Azer, 2016). In contrast, Ho \& Kahn (2014) studied number of highly cited review written by international collaborative team 
were less than those of single country team. Moreover, no correlation was found between the top-cited articles and number of countries/institutions involved (Azer, 2016).

Country of collaborators led to produce articles highly cited. Elango and Ho (2017) showed that articles of Indian researchers, who collaborate with US researchers in Science Citation Index Expanded were highly cited. Likewise, publication of Indian authors in the field of clinical pharmacology, who cooperate with US researchers in Scopus database categorized as HCA (Ahmed et al., 2017). Meanwhile, Noorhidawati et al. (2017) identified that papers of Malaysian researchers in Web of Science that cooperate with researchers from Iran, Australia and UK became HCA.

\section{Methodology}

The methodology applied was one of characteristics of HCA. Using empirical study potential became HCA (Gong et al., 2017; Jin \& Hakkarinen, 2017; Mitchell et al., 2017). Moreover, Antonakis et al. (2014) showed that articles which employ quantitative method such as SEM, meta-analysis, and theoretical approaches showed the most HCA. Additionally, applying descriptive (mean, median) and inferential statistics (experiment, causal, correlation, ANOVA, Chi-Square, t-tests, p-value, factor analysis, component analysis) made HCA (Halverson et al., 2014). Furthermore, problem-based learning (PBL) articles were assessed and reported mainly in questionnaire-based studies (Azer, 2017). However, Westgate et al. (2013) argued that empirical studies were no more highly cited than qualitative articles in the field of biodiversity.

In the field of urology and orthodontics case series were the most common study design applied (Hui et al., 2013; İpekçi et al., 2017). The majority of the top cited articles in acute kidney injury, orthopedic surgery, implant dentistry and digestive system disease were clinical studies (Fardi et al., 2017; Huo et al., 2015; Liu et al., 2016; Tang et al., 2016). Moreover, majority of HCA in limb prosthetics reviews used experimental studies (Eshraghi et al., 2013). Meanwhile, AzagraCaro et al. (2017) argued that applying developed method in patent analysis in knowledge transfer channels resulted HCA. Articles in the form of review were cited most. This factor was supported by Farr et al. (2017), who conducting research on sexual minority parent families, Hussain et al. (2014), who studying articles highly cited in journal of Nutrition \& Metabolism, and Antonakis et al. (2014), who exploring characteristics of HCA in high-impact social sciences journal, The Leadership Quarterly. Reviews and articles type dominated the majority of top cited articles (Azer, 2015). Tang et al. (2016) reported that type of review articles became the second total number of HCA.

\section{Number of pages and references}

Mazhari (2013) said that there were no correlations between the number of times articles were cited and the number of pages. Meanwhile, Branch and Linnell (2016) and Antonakis et al. (2014) conveyed that using cited articles in references will increase number of citations. 


\section{Editorial Factor}

Lin et al. (2016) studied that the shorter editorial process, the larger probabilities of becoming highly cited papers in journal Nature, Science and Physical Review Letters.

\section{Language}

Articles written in English were more cited than those of articles in other language. Buta et al. (2016) reviewed that publications in the field of frailty-related research using English were more cited than those of articles not in English. Likewise, top cited articles in orthopedic surgery and its subspecialties were written in English (Huo et al., 2015). Additionally, all articles of the 100 top-cited articles published in emergency medicine journals were written in English (Shao \& Zheng, 2016). Then, the most-cited articles in fracture surgery by Chinese authors were written in English (Dong et al., 2016). Similarly, to Martín-Martín et al. (2016), who studied highly-cited documents in Google Scholar conveyed that the average HCA was written in English.

\section{Source type}

Generally highly-cited document in Google Scholar were published in journal and available online in PDF format (Martín-Martín et al., 2016).

\section{Getting Award}

Mroz et al. (2016) studied that articles that getting award in proceeding were articles highly cited. Similarly, receiving the Karolinska Institutet Prize for research in medical education made top cited publications (Azer, 2016).

\section{The characteristics of Indonesian biodiversity articles}

Table 2 shows the comparison of biodiversity articles characteristic among three countries, Indonesia, Malaysia, and Philippines.

Table 2. The comparison of biodiversity articles characteristics of Indonesia, Malaysia, and Philippines

\begin{tabular}{|c|c|c|c|c|c|}
\hline No & Categories & Factors & Indonesia & Malaysia & Philippines \\
\hline \multirow[t]{3}{*}{1.} & Funding & $\begin{array}{c}\text { Number articles with } \\
\text { undefined funding sponsor }\end{array}$ & 560 & 393 & 195 \\
\hline & & $\begin{array}{l}\text { - Number articles with funding } \\
\text { sponsor }\end{array}$ & 148 & 102 & 190 \\
\hline & & $\begin{array}{l}\text { - Percentage of total articles with } \\
\text { funding sponsor }\end{array}$ & 20.50 & 20.61 & 69.85 \\
\hline \multirow[t]{3}{*}{2.} & $\begin{array}{l}\text { Number of } \\
\text { articles }\end{array}$ & $\begin{array}{l}\text { - Total articles with at least one } \\
\text { local author }\end{array}$ & 722 & 495 & 272 \\
\hline & & - Total of cited articles & 517 & 395 & 209 \\
\hline & & Percentage of the cited articles & 71.61 & 79.80 & 76.84 \\
\hline
\end{tabular}




3. Subject $\quad$ - The first highest of subject
- The second highest of subject
- The third highest of subject
Journal:
title level
of JIF and
H Index,
and scope
disciplines
of the
highest
journal

\begin{tabular}{|c|c|c|}
\hline $\begin{array}{c}\text { Agricultural and } \\
\text { Biological Sciences }\end{array}$ & $\begin{array}{c}\text { Agricultural } \\
\text { and Biological } \\
\text { Sciences }\end{array}$ & $\begin{array}{c}\text { Agricultural and } \\
\text { Biological } \\
\text { Sciences }\end{array}$ \\
\hline $\begin{array}{l}\text { Biochemistry, } \\
\text { Genetics and } \\
\text { Molecular Biology }\end{array}$ & $\begin{array}{l}\text { Environmental } \\
\text { Science }\end{array}$ & $\begin{array}{l}\text { Environmental } \\
\text { Science }\end{array}$ \\
\hline $\begin{array}{l}\text { Environmental } \\
\text { Science }\end{array}$ & $\begin{array}{c}\text { Biochemistry, } \\
\text { Genetics and } \\
\text { Molecular } \\
\text { Biology }\end{array}$ & $\begin{array}{c}\text { Biochemistry, } \\
\text { Genetics and } \\
\text { Molecular } \\
\text { Biology }\end{array}$ \\
\hline $\begin{array}{l}\text { Biodiversitas JIF: - } \\
\text { H Index: } 5 \\
\text { Scope: all } \\
\text { biodiversity aspects } \\
\text { of plants, animals } \\
\text { and microbes at the } \\
\text { level of gene, } \\
\text { species, and } \\
\text { ecosystem }\end{array}$ & $\begin{array}{c}\text { Journal of } \\
\text { Tropical Forest } \\
\text { Science } \\
\text { JIF: } 0.655 \\
\text { H Index: } 25 \\
\text { Scope: tropical } \\
\text { forest biology, } \\
\text { ecology, } \\
\text { chemistry, } \\
\text { management, } \\
\text { silviculture, } \\
\text { conservation, } \\
\text { utilization and } \\
\text { product } \\
\text { development. }\end{array}$ & $\begin{array}{c}\text { Zootaxa } \\
\text { JIF: } 0.931 \\
\text { H Index: } 66 \\
\text { Scope: animal } \\
\text { taxonomists }\end{array}$ \\
\hline
\end{tabular}

AACL Bioflux JIF: -

AIP Conference Proceedings H Index: 55

- The second highest of journal title

- The third highest of journal title
Scope: physical sciences, including physics, math, chemistry, materials science, and engineering.

\section{Plos One}

JIF: 2.766

H Index: 241

Scope: the natural sciences, medical research, engineering, and the related social sciences and humanities
H Index: 10 Scope: Aquaculture, Fish Genetics and Improvement, Aquarium Sciences, Fisheries, Ichthyology, Aquatic Ecology, Conservation of Aquatic Resources and Legislation

Forest Ecology \& Management JIF: 3.169

H Index: 147

forest ecology, forest management, and forest ecosystems of the world.

\begin{tabular}{|c|c|c|c|c|c|}
\hline 5. & Authorship & $\begin{array}{l}\text { - Percentage of articles with } \\
\text { single author } \\
\text { - Percentage of collaborative } \\
\text { articles } \\
\text { - Gender }\end{array}$ & $\begin{array}{c}6.37 \\
93.63 \\
\text { Not discussed }\end{array}$ & $\begin{array}{c}4.44 \\
95.56 \\
\text { Not discussed }\end{array}$ & $\begin{array}{c}92.28 \\
\text { Not discussed }\end{array}$ \\
\hline
\end{tabular}




\begin{tabular}{|c|c|c|c|c|c|}
\hline \multirow[t]{5}{*}{6.} & \multirow[t]{5}{*}{$\begin{array}{l}\text { Collaborat } \\
\quad \text { or }\end{array}$} & $\begin{array}{l}\text { - Percentage of articles with } \\
\text { international collaborative }\end{array}$ & 54.43 & 45.45 & 53.68 \\
\hline & & $\begin{array}{l}\text { - Percentage of articles with } \\
\text { local collaborative }\end{array}$ & 39.20 & 29.70 & 15.44 \\
\hline & & $\begin{array}{l}\text { The first highest of } \\
\text { collaborator affiliation and } \\
\text { country }\end{array}$ & $\begin{array}{l}\text { Universitat } \\
\text { Gottingen, } \\
\text { Netherlands }\end{array}$ & $\begin{array}{l}\text { National } \\
\text { University of } \\
\text { Singapore, } \\
\text { Singapore }\end{array}$ & $\begin{array}{l}\text { University of } \\
\text { Kansas } \\
\text { Lawrence, } \\
\text { USA }\end{array}$ \\
\hline & & $\begin{array}{l}\text { - The second highest of } \\
\text { collaborator country }\end{array}$ & $\begin{array}{l}\text { University of } \\
\text { Queensland, } \\
\text { Australia }\end{array}$ & $\begin{array}{l}\text { University of } \\
\text { Leeds, British }\end{array}$ & $\begin{array}{l}\text { James Cook } \\
\text { University, } \\
\text { Australia }\end{array}$ \\
\hline & & $\begin{array}{l}\text { The third highest of } \\
\text { collaborator country }\end{array}$ & $\begin{array}{l}\text { National University } \\
\text { of Singapore, } \\
\text { Singapore } \\
\end{array}$ & $\begin{array}{l}\text { Kyoto } \\
\text { University, } \\
\text { Japan }\end{array}$ & $\begin{array}{l}\text { University of } \\
\text { Oklahoma, USA }\end{array}$ \\
\hline \multirow[t]{2}{*}{7.} & \multirow{2}{*}{$\begin{array}{l}\text { Methodolo } \\
\text { gy }\end{array}$} & - Study design/method & Varied & Varied & Varied \\
\hline & & - Most kind of paper & Articles & Articles & Articles \\
\hline 8. & $\begin{array}{l}\text { Number of } \\
\text { pages and } \\
\text { references }\end{array}$ & & Not discussed & Not discussed & Not discussed \\
\hline 9. & $\begin{array}{l}\text { Editorial } \\
\text { Factor }\end{array}$ & & Not discussed & Not discussed & Not discussed \\
\hline 10. & Language & & English & English & English \\
\hline \multirow[t]{3}{*}{9.} & \multirow[t]{3}{*}{$\begin{array}{l}\text { Source } \\
\text { type }\end{array}$} & - The first highest of source type & Journal & Journal & Journal \\
\hline & & $\begin{array}{l}\text { - The second highest of source } \\
\text { type }\end{array}$ & $\begin{array}{l}\text { Conference } \\
\text { Proceedings }\end{array}$ & $\begin{array}{l}\text { Conference } \\
\text { Proceedings }\end{array}$ & Book Series \\
\hline & & $\begin{array}{l}\text { - The third highest of source } \\
\text { type }\end{array}$ & Books & Books & $\begin{array}{l}\text { Conference } \\
\text { Proceedings }\end{array}$ \\
\hline 10. & $\begin{array}{l}\text { Getting } \\
\text { Award }\end{array}$ & & Not discussed & Not discussed & Not discussed \\
\hline
\end{tabular}

\section{Discussions}

Five of twelve categories namely number of articles, subject, journal, authorship and method are already identified to make HCA in biodiversity discipline. Four categories among them i.e. subject, journal, authorship and methodology are the most factors discussed. This paper proposes seven categories consisting of ten factors. In this section, the paper compared and discussed the characteristics of biodiversity publication based on those factors between Indonesia and others two megadiverse Asian countries, Malaysia and Philippines.

\section{Funding}

Table 2 shows that Indonesia was on the second of the total number of articles with funding sponsor. Table 3 also shows that Indonesia had the highest total number of cited articles. However, Indonesia position was at the last of the proportion number of cited articles. 
Table 3. The data of cited articles

\begin{tabular}{lccc}
\hline \multicolumn{1}{c}{ Components } & Indonesia & Malaysia & Philippines \\
\hline Total publications with at least one local author & 722 & 495 & 272 \\
\hline Total of cited articles & & & 209 \\
\hline Percentage of the cited articles & 517 & 395 & 76.84 \\
\hline Source: Scopus & 71.61 & 79.80 & \\
\hline
\end{tabular}

Funding policy for Indonesian biodiversity is discussed in document of Indonesian Biodiversity Strategy and Action Plan (IBSAP) 2015-2020 (BAPPENAS, 2016). Funding sources are from government, private, public and foreign. However, how much percentage funding for research and publication compared to other activities such as management, training and development for society, ecotourism and SMEs is not described in the document. Since funding is one of factors affecting to citation number and driving HCA, the Indonesian government should calculate carefully in allocating any sources for biodiversity activities.

Nevertheless, most researchers in Indonesia conducted research under the government funding including researchers in the field of biodiversity. Indonesian Ministry of Research and Higher Education is providing various funding and incentives since about last five years for encouraging publication such as funding to present paper in international conferences and publish in international journals. Government also provides funding for local journals indexed in Scopus and receiving high citation rates (Lukman et al., 2018). Moreover, research institutions also provide funding for publication; for example, Center for Scientific Documentation and Information Indonesian Institute of Sciences (PDII LIPI) allocated IDR 112 million in 2018 for publication fees and IDR 90 Million for conference trips.

It shows in Table 2 that the total articles number with funding sponsor of Malaysia was below Philippines. However, Table 3 shows that the total number and proportion of cited articles of Malaysia was higher than those of Philippines. It assumed that funding does not influence the number of citations.

\section{Number of articles}

Number of Indonesian biodiversity publications in Scopus tended to increase from year to year (Yoganingrum, 2018). The increase was rapid especially in 1995 and 2006 (Handayani et al., 2016). Furthermore, Indonesia had the highest number of publications in 2017 when compared to Philippines and Malaysia (Yoganingrum, 2018). Even though number of Indonesian biodiversity publications increased steadily, the number of citations obtained was under Malaysia and Philippines. It seems that researchers have not paid attention to publish papers that will receive many citations. Researchers should have strategies to make their publications are cited, among others by appearing and monitoring the publications in social media (Jang, 2017). 


\section{Subjects/topics}

This is the most discussed factor in previous papers. Subjects or topics were assumed as one of the most essential factors for making HCAs in biodiversity discipline. Table 2 showed that the highest subjects of biodiversity were similar among Indonesia, Malaysia and Philippines. Probably it is required to be further identified the particular subjects of Indonesia biodiversity that cited most.

\section{Journal}

Journal categorize is also essential factors for making HCAs in biodiversity discipline. Most Indonesian articles were not published in journal high impact factor. It was different from Malaysia, which published mostly in journal with highly impact factor. However, Some researchers argued that there was no correlation between journal impact factor and number of citation (Chuang \& Ho, 2014, 2015; Mazhari, 2013; Pu et al., 2017).

This paper assumed that choose journal indexed in particular database become potential to have highly citation. Most researchers in the world used databases such as Scopus, WoS, Springerlink and Google Scholar to find articles as references. Therefore, journals that are not indexed by the database will be difficult accessed by researchers in the world so they will be less cited. Furthermore, choosing journals with particular disciplines scope were potential to have high citation. Table 2 showed that most publication of Malaysia and Philippines were in journals with particular scope of disciplines. Meanwhile, the second and third highest of journal of Indonesian publications were a general journal/proceeding.

\section{Authorship}

Table 2 shows that most articles of three countries that were categorized as collaborative articles. Based on Barbosa and Schneck (2015) and Parker et al. (2013) this characteristics supported for getting HCA in biodiversity.

\section{Collaborators}

Table 2 shows that the total number of international collaborative articles of three countries was higher than those of the total number of single author and local collaborative articles. This property was appropriate to have HCA (Azer, 2017; Azer \& Azer, 2016; Chuang \& Ho, 2015; Elango \& Ho, 2017; Noorhidawati et al., 2017).

Handayani et al. (2016) reported that US was the country produced the most publications about Indonesia biodiversity for 26 years, and then followed by Japan, Australia and Germany respectively. Likewise, Trianggoro et al. (2018) showed that US was in the first for several indicators such as number of publication, total publication with at least one Indonesian author, total citation of publication with at least one Indonesian author and total citation of publications with Indonesian author as the first author. However, in proportion value of those indicators, US 
was in the lower order compared to other countries. Those data means that US did not involve Indonesian researchers for all publication about Indonesian biodiversity.

Trianggoro et al. (2018) conveyed that the highest number of publications with at least one Indonesian was collaborated with Japan, France and Australia respectively. Furthermore, Indonesia publications collaborated to Canada, Netherland and UK respectively were having the highest number of citations. However, authors, participating institutions, or countries did not influence the number of top cited articles (Pu et al., 2017).

\section{Methodology}

The paper has to conduct further research to identify the most method employed by Indonesian articles. It seemed that all countries employed varied methodology. By taking the case study of Adaptive Management (AM) in biodiversity and ecosystem management in Web of Knowledge (Westgate et al., 2013) conveyed that HCA in biodiversity was not dominated by articles, which employed empirical studies. However, most articles argued that most HCA employed empirical studies (Antonakis et al., 2014; Azer, 2017; Gong et al., 2017; Halverson et al., 2014; Jin \& Hakkarinen, 2017; Mitchell et al., 2017). Furthermore, most Indonesian document type was articles and only a few articles were conference paper and book series. This type of document was potential to have HCA.

\section{Language}

The most articles of three countries applied English as language. There were only a few articles used language other than English. Meanwhile articles use English were potential to be HCA.

\section{Source type}

Most Indonesian biodiversity articles published in journals. It was similar to Malaysia and Philippines. This character supports the potential to have HCA.

\section{Conclusion}

To conclude that by concerning all factors influencing HCA would be possibility to have HCA in biodiversity. This paper proposed new factors to add existing factors to make HCA in biodiversity. Those factors were (1) funding, (2) collaborator, (3) Journal: Published period, (4) Authorship: gender (5) Methodology: kind of paper (6) Number of pages and cited references (7) Editorial Factor (8) Language (9) Source type, and (10) Getting Award.

The paper assumed that it is required to identify the particular subjects of Indonesia biodiversity that potential to be HCA. Additionally, Indonesian researchers should choose journal high impact factor with particular disciplines scope. The finding of this paper highlighted that the characteristics of Indonesian biodiversity articles were almost similar to Malaysia and Philippines in almost all factors. Factually, Indonesia was outstanding in factors, namely number 
of articles and percentage of articles with international collaborative. However, Indonesia was having lower number of citations compared to those countries. In the next research it is important to analysis the detailed factors influencing HCA in Indonesian biodiversity such as kind of funding, period of publication, the level and scope of journals, institutions/countries of collaborator, and the type of methodology.

\section{References}

Ahmad, S. S., Meyer, J. C., Krismer, A. M., Ahmad, S. S., Evangelopoulos, D. S., Hoppe, S., \& Kohl, S. (2017). Outcome measures in clinical ACL studies: an analysis of highly cited level I trials. Knee Surgery, Sports Traumatology, Arthroscopy, 25(5), 1517-1527. http://doi.org/10.1007/s00167-016-4334-4

Ahmed, K. K. M., Dhawan, S. M., Gupta, B. M., \& Bansal, M. (2017). Highly cited publications output by India in clinical pharmacology during 2000-14: A scientometric assessment. Journal of Young Pharmacists, 9(2), 145-157. http://doi.org/10.5530/jyp.2017.9.30

Antonakis, J., Bastardoz, N., Liu, Y., \& Schriesheim, C. A. (2014). What makes articles highly cited? Leadership Quarterly, 25(1), 152-179. http://doi.org/10.1016/j.leaqua.2013.10.014

Azagra-Caro, J. M., Barberá-Tomás, D., Edwards-Schachter, M., \& Tur, E. M. (2017). Dynamic interactions between university-industry knowledge transfer channels: A case study of the most highly cited academic patent. Research Policy, 46(2), 463-474. http://doi.org/10.1016/j.respol.2016.11.011

Azer, S. A. (2015). The Top-Cited Articles in Medical Education: A Bibliometric Analysis. Academic Medicine, 90(8), 1147-1161. http://doi.org/10.1097/ACM.0000000000000780

Azer, S. A. (2016). Exploring the Top-Cited and Most Influential Articles in Medical Education. The Journal of Continuing Education in the Health Professions, 36, S32-S41. http://doi.org/10.1097/CEH.0000000000000085

Azer, S. A. (2017). Top-cited articles in problem-based learning: A bibliometric analysis and quality of evidence assessment. Journal of Dental Education, 81(4), 458-478. http://doi.org/10.21815/JDE.016.011

Azer, S. A., \& Azer, S. (2016). Bibliometric analysis of the top-cited gastroenterology and hepatology articles. BMJ Open, 6(2). http://doi.org/10.1136/bmjopen-2015-009889

BAPPENAS. (2016). Indonesian Biodiversity Strategy and Action Plan (IBSAP) 2015-2020. Jakarta. Retrieved from https://www.bappenas.go.id/files/publikasi_utama/Dokumen_IBSAP_20152020.pdf

Barbosa, F. G., \& Schneck, F. (2015). Characteristics of the top-cited papers in species distribution predictive models. $\quad$ Ecological Modelling, 313, 77-83. http://doi.org/10.1016/j.ecolmodel.2015.06.014

Bauer, J., Leydesdorff, L., \& Bornmann, L. (2016). Highly cited papers in Library and Information Science (LIS): Authors, institutions, and network structures. Journal of the Association for Information Science and Technology, 67(12). http://doi.org/10.1002/asi.23568 
Bohl, M. A., \& Ponce, F. A. (2017). Assessing the Relevancy of Highly Cited Works in Neurosurgery. Part I: The 100 Most Relevant Papers in Neurosurgical Journals. World Neurosurgery, 104, 927-938. http://doi.org/10.1016/j.wneu.2017.03.149

Branch, T. A., \& Linnell, A. E. (2016). What makes some fisheries references highly cited? Fish and Fisheries, 17(4), 1094-1133. http://doi.org/10.1111/faf.12160

Brown, T., Gutman, S. A., Ho, Y.-S., \& Fong, K. N. K. (2017). Highly cited occupational therapy articles in the science citation index expanded and social sciences citation index: A bibliometric analysis. American Journal of Occupational Therapy, 71(6). http://doi.org/10.5014/ajot.2017.023747

Buta, B. J., Walston, J. D., Godino, J. G., Park, M., Kalyani, R. R., Xue, Q.-L., .. Varadhan, R. (2016). Frailty assessment instruments: Systematic characterization of the uses and contexts of highlycited instruments. Ageing Research Reviews, 26, 53-61. http://doi.org/10.1016/j.arr.2015.12.003

Chen, H., \& Ho, Y.-S. (2015). Highly cited articles in biomass research: A bibliometric analysis. $\begin{array}{llll}\text { Renewable } \quad \text { and } & \text { Sustainable }\end{array}$ http://doi.org/10.1016/j.rser.2015.04.060

Chen, L.-M., Liu, Y.-Q., Shen, J.-N., Peng, Y.-L., Xiong, T.-Y., Tong, X., ... Zhang, Y.-G. (2015). The 100 top-cited tuberculosis research studies. International Journal of Tuberculosis and Lung Disease, 19(6), 717-722. http://doi.org/10.5588/ijtld.14.0925

Chen, S., Arsenault, C., \& Larivière, V. (2015). Are top-cited papers more interdisciplinary? Journal of Informetrics, 9(4), 1034-1046. http://doi.org/10.1016/j.joi.2015.09.003

Chuang, K.-Y., \& Ho, Y.-S. (2014). Bibliometric profile of top-cited single-author articles in the Science Citation Index Expanded. Journal of Informetrics, 8(4), 951-962. http://doi.org/10.1016/j.joi.2014.09.008

Chuang, K.-Y., \& Ho, Y.-S. (2015). An evaluation based on highly cited publications in Taiwan. Current Science, 108(5), 933-941.

Ciliberto, A., Novak, B., \& Tyson, J. J. (2009). In their own words: Interviews with Cell Cycle - John J. Tyson on his highly cited paper. Cell Cycle, 8(20), 3261.

Clarivate Analytics. (2017). Look up to the brightest stars Introducing 2017's Highly Cited Researchers. Web of Science. Retrieved from https://hcr.clarivate.com/wpcontent/uploads/2017/11/2017-Highly-Cited-Researchers-Report-1.pdf

Ding, F., Jia, Z., \& Liu, M. (2016). National representation in the spine literature: a bibliometric analysis of highly cited spine journals. European Spine Journal, 25(3), 850-855. http://doi.org/10.1007/s00586-015-4204-7

Dong, F., Fan, M., \& Jia, Z. (2016). Fifty top-cited fracture articles from China: A systematic review and bibliometric analysis. Journal of Orthopaedic Surgery and Research, 11(1). http://doi.org/10.1186/s13018-016-0408-8

Elango, B., \& Ho, Y.-S. (2017). A bibliometric analysis of highly cited papers from India in Science Citation Index Expanded. Current Science, 112(8), 1653-1658. http://doi.org/10.18520/cs/v112/i08/1653-1658 
Elfahmi, Woerdenbag, H. J., \& Kayser, O. (2014). Jamu: Indonesian traditional herbal medicine towards rational phytopharmacological use. Journal of Herbal Medicine, 4(2), 51-73.

Eshraghi, A., Osman, N. A. A., Gholizadeh, H., Ali, S., \& Shadgan, B. (2013). 100 top-cited scientific papers in limb prosthetics. BioMedical Engineering Online, 12(1). http://doi.org/10.1186/1475925X-12-119

Fardi, A., Kodonas, K., Lillis, T., \& Veis, A. (2017). Top-cited articles in implant dentistry. International Journal of Oral and Maxillofacial Implants, 32(3), 555-564. http://doi.org/10.11607/jomi.5331

Farr, R. H., Tasker, F., \& Goldberg, A. E. (2017). Theory in Highly Cited Studies of Sexual Minority Parent Families: Variations and Implications. Journal of Homosexuality, 64(9), 1143-1179. http://doi.org/10.1080/00918369.2016.1242336

Fu, H.-Z., \& Ho, Y.-S. (2015). Top cited articles in thermodynamic research. Journal of Engineering Thermophysics, 24(1), 68-85. http://doi.org/10.1134/S1810232815010075

Fu, H.-Z., \& Ho, Y.-S. (2016). Highly cited Antarctic articles using Science Citation Index Expanded: a bibliometric analysis. Scientometrics, 109(1), 337-357. http://doi.org/10.1007/s11192-0161992-4

Gong, B., Wu, Y., O’Keeffe, M. E., Berger, F. H., McLaughlin, P. D., Nicolaou, S., \& Khosa, F. (2017). Top 50 highly cited articles on dual energy computed tomography (DECT) in abdominal radiology: A bibliometric analysis. Polish Journal of Radiology, 82, 748-759. http://doi.org/10.12659/PJR.904075

González-Betancor, S. M., \& Dorta-González, P. (2017). An indicator of the impact of journals based on the percentage of their highly cited publications. Online Information Review, 41(3), 398-411. http://doi.org/10.1108/OIR-01-2016-0008

Gutman, S. A., Brown, T., \& Ho, Y.-S. (2017). A Bibliometric Analysis of Highly Cited and High Impact Occupational Therapy Publications by American Authors. Occupational Therapy in Health Care, 31(3), 167-187. http://doi.org/10.1080/07380577.2017.1326192

Halverson, L. R., Graham, C. R., Spring, K. J., Drysdale, J. S., \& Henrie, C. R. (2014). A thematic analysis of the most highly cited scholarship in the first decade of blended learning research. Internet and Higher Education, 20, 20-34. http://doi.org/10.1016/j.iheduc.2013.09.004

Handayani, T., Amelia, M., Rahmaida, R., Hardiyati, R., \& Nadhiroh, I. M. (2016). Kajian Saintometrika Perkembangan Publikasi Ilmiah Keanekaragaman Hayati Indonesia Sebagai Bahan Rekomendasi Kebijakan Arah Penelitian Keanekaragaman Hayati Nasional. (Laporan Penelitian No. 2017-01-01-12.).

Ho, Y.-S. (2013). The top-cited research works in the Science Citation Index Expanded. Scientometrics, 94(3), 1297-1312. http://doi.org/10.1007/s11192-012-0837-z

Ho, Y.-S. (2014). A bibliometric analysis of highly cited articles in materials science. Current Science, 107(9), 1565-1572. 
Ho, Y.-S., \& Kahn, M. (2014). A bibliometric study of highly cited reviews in the Science Citation Index Expanded $^{\mathrm{TM}}$. Journal of the American Society for Information Science and Technology, 65(2), 372-385. http://doi.org/10.1002/asi.22974

Hong, S. J., Lim, K. J., Hwang, H. J., Baek, S., Seo, Y. L., Yun, E. J., .. Yoon, D. Y. (2017). The 100 Top-cited articles in pulmonary imaging. Journal of Thoracic Imaging, 32(3), 198-202. http://doi.org/10.1097/RTI.0000000000000251

Hsu, Y.-H. E., \& Ho, Y.-S. (2014). Highly cited articles in health care sciences and services field in science citation index expanded: A bibliometric analysis for 1958 - 2012. Methods of Information in Medicine, 53(6), 446-458. http://doi.org/10.3414/ME14-01-0022

Hui, J., Han, Z., Geng, G., Yan, W., \& Shao, P. (2013). The 100 top-cited articles in orthodontics from 1975 to 2011. Angle Orthodontist, 83(3), 491-499. http://doi.org/10.2319/040512-284.1

Huo, Y.-Q., Pan, X.-H., Li, Q.-B., Wang, X.-Q., Jiao, X.-J., Jia, Z.-W., \& Wang, S.-J. (2015). Fifty topcited classic papers in orthopedic elbow surgery: A bibliometric analysis. International Journal of Surgery, 18, 28-33. http://doi.org/10.1016/j.ijsu.2015.03.020

Hussain, M. M., Abel, L., \& Bakillah, A. (2014). Nutrition \& metabolism classics: A disconnect between highly cited and highly accessed articles. Nutrition and Metabolism, 11(1). http://doi.org/10.1186/1743-7075-11-13

İpekçi, T., Yüksel, M., \& Tunçkıran, A. (2017). Top cited articles in urology from Turkey. Turk Uroloji Dergisi, 43(1), 62-67. http://doi.org/10.5152/tud.2016.98958

Jang, H. (2017). Should we wait until an article is cited? Science Editing, 4(1), 39-40.

Jin, P., \& Hakkarinen, M. (2017). Highlights in bioethics through 40 years: A quantitative analysis of top-cited journal articles. Journal of Medical Ethics, 43(5), 339-345. http://doi.org/10.1136/medethics-2016-103658

Khan, M. S., Usman, M. S., Fatima, K., Hashmani, N., Siddiqi, T. J., Riaz, H., ... Khosa, F. (2017). Characteristics of Highly Cited Articles in Interventional Cardiology. American Journal of Cardiology, 120(11), 2100-2109. http://doi.org/10.1016/j.amjcard.2017.08.030

Khan, N. R., Lee, S. L., Brown, M., Reding, J., Angotti, J., Lepard, J., ... Michael L.M., I. I. (2015). Highly cited works in skull base neurosurgery. World Neurosurgery, 83(4), 403-418. http://doi.org/10.1016/j.wneu.2014.12.005

Kolle, S. R., Shankarappa, T. H., \& Ho, Y.-S. (2017). Highly cited articles in science citation index expanded - subject category of horticulture: A bibliometric analysis [Meistzitierte Artikel im Science Citation Index Expanded - Themenkategorie Gartenbau: Eine bibliometrische Analyse]. Erwerbs-Obstbau, 59(2), 133-145. http://doi.org/10.1007/s10341-016-0308-4

Lenzi, R., Fortunato, S., \& Muscatello, L. (2016). Top-cited articles of the last 30 years (1985-2014) in otolaryngology - Head and neck surgery. Journal of Laryngology and Otology, 130(2), 121127. http://doi.org/10.1017/S002221511500300X

Lin, Z., Hou, S., \& Wu, J. (2016). The correlation between editorial delay and the ratio of highly cited papers in Nature, Science and Physical Review Letters. Scientometrics, 107(3), 1457-1464. http://doi.org/10.1007/s11192-016-1936-z 
Liu, Y.-H., Wang, S.-Q., Xue, J.-H., Liu, Y., Chen, J.-Y., Li, G.-F., ... Tan, N. (2016). Hundred topcited articles focusing on acute kidney injury: A bibliometric analysis. BMJ Open, 6(7). http://doi.org/10.1136/bmjopen-2016-011630

Lukman, L., Rianto, Y., Al Hakim, S., Nadhiroh, I. M., \& Hidayat, D. S. (2018). Citation performance of Indonesian scholarly journals indexed in Scopus from Scopus and Google Scholar. Science Editing, 5(1), 53-58. http://doi.org/10.6087/kcse.119

Ma, J., Fu, H.-Z., \& Ho, Y.-S. (2013). The top-cited wetland articles in science citation index expanded: Characteristics and hotspots. Environmental Earth Sciences, 70(3), 1039-1046. http://doi.org/10.1007/s12665-012-2193-y

Martín-Martín, A., Orduna-Malea, E., Ayllón, J. M., \& López-Cózar, E. D. (2016). A two-sided academic landscape: snapshot of highly-cited documents in Google Scholar (1950-2013). Revista Espanola de Documentacion Cientifica, 39(4). http://doi.org/10.3989/redc.2016.4.1405

Mazhari, S. (2013). The 100 top-cited articles published in psychiatric journals. Journal of Psychiatric Practice, 19(4), 327-338. http://doi.org/10.1097/01.pra.0000432604.06835.da

Mitchell, B., Cristancho, S., Nyhof, B. B., \& Lingard, L. A. (2017). Mobilising or standing still? A narrative review of Surgical Safety Checklist knowledge as developed in 25 highly cited papers from 2009 to 2016. BMJ Quality and Safety, 26(10), 837-844. http://doi.org/10.1136/bmjqs2016-006218

Mroz, T. P., Clarke, H. D., Chang, Y.-H. H., \& Scuderi, G. R. (2016). Knee Society Award Papers Are Highly Cited Works. Clinical Orthopaedics and Related Research, 474(1), 96-100. http://doi.org/10.1007/s11999-015-4330-x

Munzer, B. W., Love, J., Shipman, B. L., Byrne, B., Cico, S. J., Furlong, R., ... Santen, S. A. (2017). An analysis of the top-cited articles in emergency medicine education literature. Western Journal of Emergency Medicine, 18(1), 60-68. http://doi.org/10.5811/westjem.2016.10.31492

Nardi, P., Di Matteo, G., Palahi, M., \& Scarascia Mugnozza, G. (2016). Structure and evolution of mediterranean forest research: A science mapping approach. PLoS ONE, 11(5). http://doi.org/10.1371/journal.pone.0155016

Noorhidawati, A., Aspura, M. K. Y. I., Zahila, M. N., \& Abrizah, A. (2017). Characteristics of Malaysian highly cited papers. Malaysian Journal of Library and Information Science, 22(2), 85-99. http://doi.org/10.22452/mjlis.vol22no2.6

Pagni, M., Khan, N. R., Cohen, H. L., \& Choudhri, A. F. (2014). Highly cited works in radiology: The top 100 cited articles in radiologic journals. Academic Radiology, 21(8), 1056-1066. http://doi.org/10.1016/j.acra.2014.03.011

Parker, J. N., Allesina, S., \& Lortie, C. J. (2013). Characterizing a scientific elite (B): Publication and citation patterns of the most highly cited scientists in environmental science and ecology. Scientometrics, 94(2), 469-480. http://doi.org/10.1007/s11192-012-0859-6

Peter, M. E. (2009). An interview with Dr. Marcus E. Peter on his highly cited paper published in Cell Cycle. Cell Cycle (Georgetown, Tex.), 8(15), 2325. http://doi.org/10.4161/cc.8.15.9127 
Pu, Q.-H., Lyu, Q.-J., Liu, H., \& Fan, K.-H. (2017). Bibliometric analysis of the top-cited articles on islet transplantation. Medicine, 96(44), e8247. http://doi.org/10.1097/MD.0000000000008247

Pyšek, P., Richardson, D. M., \& Jarošík, V. (2006). Who cites who in the invasion zoo: Insights from an analysis of the most highly cited papers in invasion ecology. Preslia, 78(4), 437-468.

Rangel, J. C., Cartmill, C., Martimianakis, M. A., Kuper, A., \& Whitehead, C. R. (2017). In search of educational efficiency: 30 years of Medical Education's top-cited articles. Medical Education, 51(9), 918-934. http://doi.org/10.1111/medu.13349

Ríos-Saldaña, C. A., Delibes-Mateos, M., \& Ferreira, C. C. (2018). Are fieldwork studies being relegated to second place in conservation science? Global Ecology and Conservation, 14, e00389. http://doi.org/10.1016/j.gecco.2018.e00389

Secretariat, of the C. on B. D. (SCBD). (2017). Indonesia country profile: Biodiversity Facts. $\begin{array}{llll}\text { Retrieved } & \text { September } & \text { 1, 2018, from }\end{array}$ https://www.cbd.int/countries/profile/default.shtml?country=id\#facts

Shao, J. F., \& Zheng, X. T. (2016). The 100 top-cited articles published in emergency medicine journals: A bibliometric analysis. Hong Kong Journal of Emergency Medicine, 23(6), 329-339. http://doi.org/10.1177/102490791602300602

Sharma, B., \& Lawrence, D. W. (2014). Top-cited articles in traumatic brain injury. Frontiers in Human Neuroscience, 8(November). http://doi.org/10.3389/fnhum.2014.00879

Tahamtan, I., Safipour Afshar, A., \& Ahamdzadeh, K. (2016). Factors affecting number of citations: a comprehensive review of the literature. Scientometrics, 107(3), 1195-1225. http://doi.org/10.1007/s11192-016-1889-2

Tang, X., Gong, W., Yuan, F., Li, R., Han, X., Huang, S., ... Jiang, B. (2016). Top-cited articles in digestive system disease from 1950 to 2013. Journal of Gastroenterology and Hepatology (Australia), 31(1), 107-111. http://doi.org/10.1111/jgh.13032

Thelwall, M., Kousha, K., \& Abdoli, M. (2017). Is medical research informing professional practice more highly cited? Evidence from AHFS DI Essentials in drugs.com. Scientometrics, 112(1), 509-527. http://doi.org/10.1007/s11192-017-2292-3

Trianggoro, C., Ayunda, W. A., Rahma, N. M., \& Yoganingrum, A. (2018). Contribution of Indonesian researchers in International multi authored authored biodiversity publication. In 2nd International Conference on Innovative Research in Science, Technology \& Management.

Viglietto, G. (2009). In their own words: Interviews with Cell Cycle - Giuseppe Viglietto on his highly cited paper. Cell Cycle, 8(18), 2869-2870. http://doi.org/10.4161/cc.8.18.9757

Westgate, M. J., Likens, G. E., \& Lindenmayer, D. B. (2013). Adaptive management of biological $\begin{array}{lllll}\text { systems: } & \text { A } & \text { review. Biological } & \text { Conservation, 128-139. }\end{array}$ http://doi.org/10.1016/j.biocon.2012.08.016

Wilcox, M. A., Khan, N. R., McAbee, J. H., Boop, F. A., \& Klimo Jr., P. (2013). Highly cited publications in pediatric neurosurgery. Child's Nervous System, 29(12), 2201-2213. http://doi.org/10.1007/s00381-013-2228-z 
Yang, X., Gu, J., Yan, H., Xu, Z., Ren, B., Yang, Y., ... Tan, S. (2014). The highly-cited Electrocardiogram-related articles in science citation index expanded: Characteristics and $\begin{array}{llll}\text { hotspots. } \quad \text { Journal } & \text { 738-744. }\end{array}$ http://doi.org/10.1016/j.jelectrocard.2014.03.005

Yi, F. X., Ma, J., Ni, W. M., Chang, R., Liu, W. D., Han, X. B., .. Qiu, J. W. (2013). The top cited articles on glioma stem cells in Web of Science. Neural Regeneration Research, 8(15), 14311438. http://doi.org/10.3969/j.issn.1673-5374.2013.15.011

Yoganingrum, A. (2018). The Biodiversity Research Outputs of the Megadiverse Asean. In The $31^{s t}$ International Business Information Management Association Conference (pp. 5604-5613).

Yoon, D. Y., Yun, E. J., Ku, Y. J., Baek, S., Lim, K. J., Seo, Y. L., \& Yie, M. (2013). Citation classics in radiology journals: The 100 top-cited articles, 1945-2012. American Journal of Roentgenology, 201(3), 471-481. http://doi.org/10.2214/AJR.12.10489

Zhang, F., Yan, E., Niu, X., \& Zhu, Y. (2018). Joint modeling of the association between NIH funding and its three primary outcomes: patents, publications, and citation impact. Scientometrics. http://doi.org/10.1007/s11192-018-2846-z

Zhang, J. J., \& Guan, J. (2017). Scientific relatedness and intellectual base: a citation analysis of uncited and highly-cited papers in the solar energy field. Scientometrics, 110(1), 141-162. http://doi.org/10.1007/s11192-016-2155-3

Zhang, Y., Huang, J., \& Du, L. (2017). The top-cited systematic reviews/meta-analyses in tuberculosis research: A PRISMA-compliant systematic literature review and bibliometric analysis. Medicine (United States), 96(6). http://doi.org/10.1097/MD.0000000000004822

\section{Bibliographic information of this paper for citing:}

Yoganingrum, A. (2020). "How to make biodiversity articles highly cited?" Webology, 17(1), Article 211. Available at: http://www.webology.org/2020/v17n1/a211.pdf

Copyright (C) 2020, Ambar Yoganingrum. 